\title{
Metabolism of Ovomucoid by the Developing Chick Embryo ${ }^{1}$
}

THEODORE R. OEGEMA, JR. ${ }^{2}$ AND GEORGE W. JOURDIAN

Rackham Arthritis Research Unit and the Department of Biological Chemistry, The University of Michigan Medical School,

Ann Arbor, Michigan 48104

\begin{abstract}
A glycoprotein resembling ovomucoid was purified from chorioallantoic membranes of 12.5 day chick embryos by a sequential procedure involving zinc chloride precipitation, hydroxylapatite chromatography, and ion exchange chromatography on DEAE- and CM-cellulose. The resulting preparation was homogeneous as indicated by polyacrylamide gel electrophoresis at $3 \mathrm{pH}$ values, isoelectric focusing, ultracentrifugation, and immunochemical analysis. The purified material had an isoelectric point of 4.8 , molecular weight of 29,500 and contained 1.6 moles of galactose, 7.7 moles of mannose, 22.8 moles of $\mathrm{N}$-acetylglucosamine and 0.4 mole of glucose per mole of protein. The ovomucoid fraction inhibited bovine trypsin, forming a 1 to 1 complex on a molar basis, and elicited a positive anaphylactoid response in albino rats at levels as low as $0.5 \mu \mathrm{g}$. A specific ovomucoid antiserum was obtained from rabbits that allowed investigation of the mobilization and metabolism of ovomucoid in the developing chick embryo. These studies revealed that between days 12 and 13 of embryo development a progressive migration of ovomucoid occurs from the albumin sac to the amnionic sac. The glycoprotein is then swallowed and transported through the gut to the yolk sac, where it is catabolized by proteases and glycosidases contained in the yolk sac membrane. Between day 12 of embryo development and day 7 after hatching, ovomucoid appeared in the serum of the chick and reached a maximum value of $2.4 \mathrm{mg} \%$ on day 18 of embryo development.
\end{abstract}

Ovomucoid, a glycoprotein first described by Mörner (1894), comprises nearly $10 \%$ of egg white protein. The unique chemical and biological properties of ovomucoid continue to be subjects of interest; these properties include (1) high solubility in salts, organic solvents and trichloroacetic acid, (2) an ability to serve as a trypsin inhibitor, and (3) an ability to elicit an anaphylactoid response in albino rats.

Studies on the nature and composition of ovomucoid have been restricted by the apparent heterogeneity of the proteinpolysaccharide complex and by the lack of generally applicable methodology to isolate ovomucoid fractions in a homogeneous undegraded state. The classic procedures of Lineweaver and Murray (47) and Fredricq and Deutsch (49) have served as starting points for the purification of ovomucoid by a variety of techniques employing protein denaturants. Attempts to purify ovomucoid without the use of protein denaturants have also been reported (Lin and Feeney, '72).

Little is known concerning the mobilization and metabolism of ovomucoid in the developing chick embryo. Isolated aspects of these processes have been investigated and are summarized in the papers of Romanoff ('52, '60) and Foote (69).

The demonstration of glucosyltransferase activity in chick embryo tissues distinct from those involved in glycogen and collagen biosynthesis (Distler and Jourdian, 72) prompted the authors to examine a number of tissues for glucose-containing polymers. A novel homogeneous glucosecontaining ovomucoid fraction was isolated from chick embryo chorioallantoic

\footnotetext{
1 This work was supported by Grant AM-10531 from the National Institute of Arthritis, Metabolic and Digestive Diseases, National Institutes of Health.

2 Predoctoral Fellow, National Science Foundation. Current address: Department of Oral Biology, School of Dentistry, University of Michigan, Ann Arbor, Michig an 48104.
} 
membranes by a modification of the procedure previously reported for egg white ovomucoid (Oegema and Jourdian, '74). The present manuscript describes the isolation and characterization of this glycoprotein, preparation of specific antiserum against this material, and use of this antiserum to follow the metabolic fate of ovomucoid in the developing chick embryo.

\section{MATERIALS AND METHODS}

The following materials were obtained from the indicated sources: Chlorella ${ }^{14} \mathrm{C}$ protein hydrolysate (specific activity, 52 $\mathrm{mCi} / \mathrm{milliatom}$ carbon), Amersham Searle, Arlington Heights, Ill.; sodium borotritide (100 mCi/12.6 mg), New England Nuclear, Boston, Mass.; 2-acetamido-1- $\beta$-L- $(\beta$-aspartyl)-1,2 dideoxy-D-glycopyranosylamine (asparaginyl- $N$-ac etylglucosaminide); $p$ nitrophenyl $-\beta-N$-acetylgalactosaminide, $\mathrm{Cy}-$ clo Chemical Co., Los Angeles, Calif.; 1dimethylamino - napthalene - 5 - sulphonylchloride and dansylated amino acids, $p$ nitrophenyl- $\alpha$-D-mannopyranoside, $p$-nitrophenyl- $\beta$-D-galactopyranoside, $p$-nitrophenyl- $\alpha$-D-galactopyranoside, $p$-nitrophenyl- $\alpha$ D-glucopyranoside, $\quad p$-nitrophenyl- $\beta$-D-glucopyranoside, $p$-nitrophenyl- $\beta$ - $N$-acetylglucosaminide, Pierce Laboratories, Rockford, Ill.; $p$-nitrophenyl- $\beta$-D-mannopyranoside, Sigma Chemical Co., St. Louis, Mo.

Commonly used chemicals and solvents were obtained from commercial sources and were of reagent quality or of the best quality available. Enzymes and proteins employed in the presently described studies were obtained from the indicated sources: Pronase (grade B), Calbiochem, Los Angeles, Calif.; recrystallized $2 \times$ salt-free trypsin (9000 units/mg), Boehringer Mannheim, New York, N.Y.; recrystallized $3 \times$ salt-free $\alpha$-chymotrypsin (45 units/mg), Worthington Biochemical Co., Freehold, N.J.; molecular weight marker kit, Schwarz-Mann Research Laboratories, New York, N.Y. Gel filtration media and ion exchange resins were obtained from the following sources and were prepared according to manufacturer's directions: DEAE-cellulose (DE-32) and CM-cellulose (CM-32), Reeve Angel, Clifton, N.J.: Biogel P-2, P-6, P-10, and hydroxylapatite (Biogel HT), BioRad Laboratories, Richmond, Calif.; Dowex-1 (chloride) $\times 8(200$ to 400 mesh), Dow Chemical Co., Midland,
Mi.; Dowex-50 (hydrogen) $\times 2$ (200 to 400 mesh), Sigma Chemical Co., St. Louis, Mo. Fertile White Leghorn eggs were obtained from the Singing Hills Poultry Farm, Manchester, Mi. Eggs were incubated at $37^{\circ} \mathrm{C}$ in a humidified atmosphere for varying time periods.

\section{Analytical procedures}

Protein was determined by the method of Lowry et al. (51). Crystalline bovine serum albumin served as reference standard. Total hexose was determined by a phenol-sulfuric acid method (Dubois et al., '56) and hexosamine content by the procedure of Roseman and Daffner ('56) after hydrolysis with $4 N$ hydrochloric acid at $100^{\circ} \mathrm{C}$ for 8 hours. Sialic acid was quantitated by the method of Jourdian et al. (71). Neutral sugars were quantitated by gas-liquid chromatography as their $\mathrm{O}$-acetylglycitol derivatives after resin-mediated acid hydrolysis (Lehnhardt and Winzler, '68).

For qualitative identification of the neutral sugars and hexosamines, $1 \mathrm{mg}$ samples of chorioallantoic membrane ovomucoid (CM-OV) were hydrolyzed in $4 \mathrm{~N}$ hydrochloric acid at $100^{\circ} \mathrm{C}$ for varying time periods ( 1 to 4 hours). Solutions were neutralized with Dowex-1 (bicarbonate) $\times 8$ (200 to $400 \mathrm{mesh}$ ) and passed through a $1 \mathrm{ml}$ column of Dowex-50 (hydrogen) $\times 8$ (200 to 400 mesh). The sugars contained in the neutral fraction $(10 \mathrm{ml})$ were identified by paper chromatography (described below). The hexosamine fraction was eluted with $0.5 \mathrm{~N} \mathrm{HCl}$, dried, $\mathrm{N}$-acetylated (Roseman and Ludowieg, '54), and identified by paper chromatography and paper electrophoresis (described below).

\section{Polyacrylamide disc gel electrophoresis}

Discontinuous polyacrylamide gel electrophoresis was performed in $7 \%$ gel columns at $\mathrm{pH}$ values of $2.3,{ }^{3} 4.3$ (Reisfeld et al., '62), and 9.5 (Davis, '64 and Ornstein, '64). Proteins were stained with Coomassie Blue (Chramback et al., 67). Minimum molecular weights were determined in polyacrylamide gel columns in the presence of sodium dodecylsulfate and $\beta$-mercaptoethanol (Weber and Osborn, '69).

\footnotetext{
3 Performed according to the directions of Canalco, Bethesda, Maryland.
} 
The isoelectric point of CM-OV preparations was determined by isoelectric focusing in polyacrylamide gel (Catsimpoolas, '68).

\section{Physical characterization of $\mathrm{CM}-\mathrm{OV}$}

Sedimentation coefficients were determined with a Beckman Spinco Model E analytical ultracentrifuge equipped with Schlieren optics. The CM-OV protein preparations were centrifuged at $59,780 \mathrm{rpm}$ at $20^{\circ} \mathrm{C}$ in cells equipped with quartz windows and an Epon centerpiece with a $12 \mathrm{~mm}$ optical path. The CM-OV preparations ( 5 to $15 \mathrm{mg} / \mathrm{ml}$ ) were dialyzed before use against a $0.10 \mathrm{M} \mathrm{KCl}$ to $0.05 \mathrm{M}$ potassium phosphate buffer, $\mathrm{pH}$ 6.8. The $\mathrm{s}_{20, w}$ values were obtained in the manner described by Chervenka ('69). Diffusion constants were calculated from the same runs and corrected to $D_{20, w}$ (Chervenka, '69). A partial specific volume of 0.695 was calculated from the partial specific values of the constituent amino acids (Edsall, "43) and sugars (Gibbons, '72). ${ }^{4}$

\section{Biological characterization of $\mathrm{CM}-\mathrm{OV}$}

The anaphylactoid reaction described by Selye (37) was investigated in albino rats using the dermal assay of Halpern (56). The test solutions contained between 0.5 and $100 \mu \mathrm{g}$ of ovomucoid per $0.01 \mathrm{ml}$ of saline. Bovine serum albumin (1 $\mathrm{mg} /$ $\mathrm{ml}$ ) and saline served as negative controls. A positive reaction was taken as the appearance of blue coloration in the areas of injection due to a change in the permeability of the capillaries to Evan's Blue dye-protein complex.

Inhibition of trypsin esterase activity was measured by the procedure of Green ('53) with $\alpha$ - $N$-benzylarginylethyl ester (Schwert and Takenaka, '55).

For the preparation of antibodies to purified CM-OV, the footpads and intrascapular regions of New Zealand Giant White rabbits (2 to $3 \mathrm{~kg}$ ) were injected with CM-OV $(0.4 \mathrm{mg})$ at 2 week intervals for 6 weeks. The challenging injections were prepared by homogenizing equal volumes of CM-OV (2 mg/ml) and complete Freund's adjuvant. Animals which failed to respond to the antigen were given 6 intravenous injections of antigen $(0.3 \mathrm{mg}$ per injection) at 3 day intervals and bled on the seventh day after the last injection.

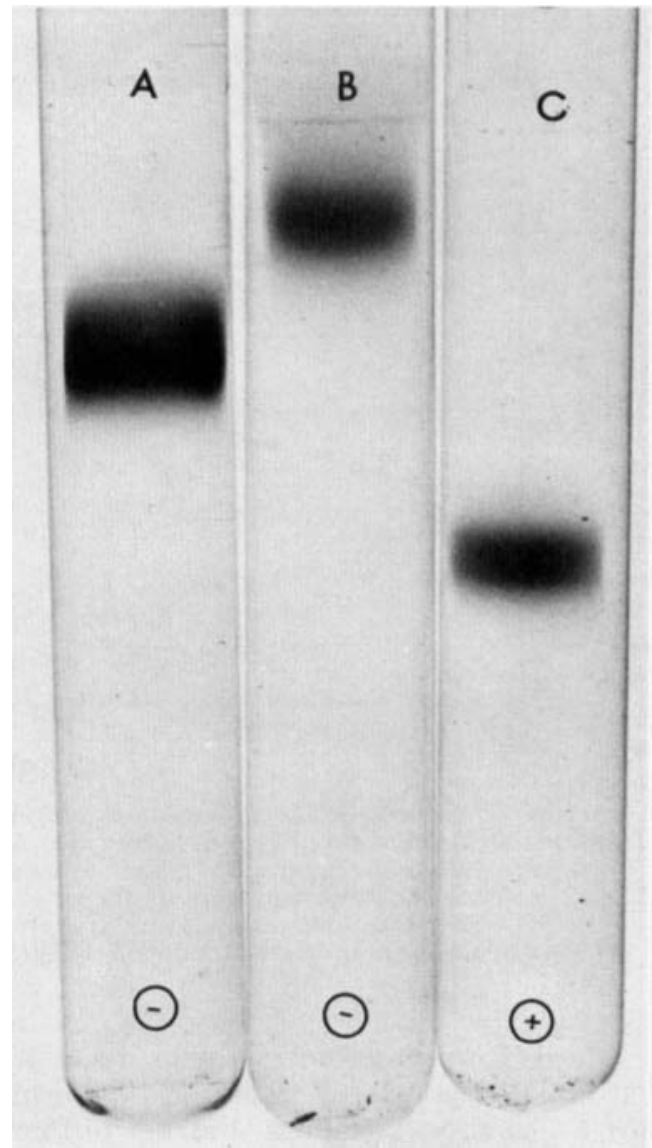

Fig. 1 Discontinuous polyacrylamide gel electrophoresis of chorioallantoic membrane ovomucoid (CM-OV, $100 \mu \mathrm{g} / \mathrm{gel}$ ). Electrophoresis buffer systems employed were: A, pH 2.8; B, pH 4.3; and $\mathrm{C}, \mathrm{pH}$ 9.5. The experimental procedure was that described in MATERIALS AND METHODS.

Double diffusion studies were carried out by a modified Ouchterlony procedure (Crowle, '61). Immunoelectrophoresis was performed by the procedure of Grabar and Williams (53); the slides were washed overnight with saline, washed with distilled water, dried, and stained with AmidoSchwartz (Maurer, '71).

The concentration of ovomucoid in serum samples was quantitated by a modification of the immunoelectrophoretic method of Laurell (66). Ovomucoid (CM-OV, 0.05 to $1.1 \mu \mathrm{g} / 2 \mu \mathrm{l}$ ) served as reference

\footnotetext{
${ }^{4}$ We gratefully acknowledge the assistance of Drs. C. Williams and D. Burleigh in the quantitative amino acid analysis of CM-OV.
} 


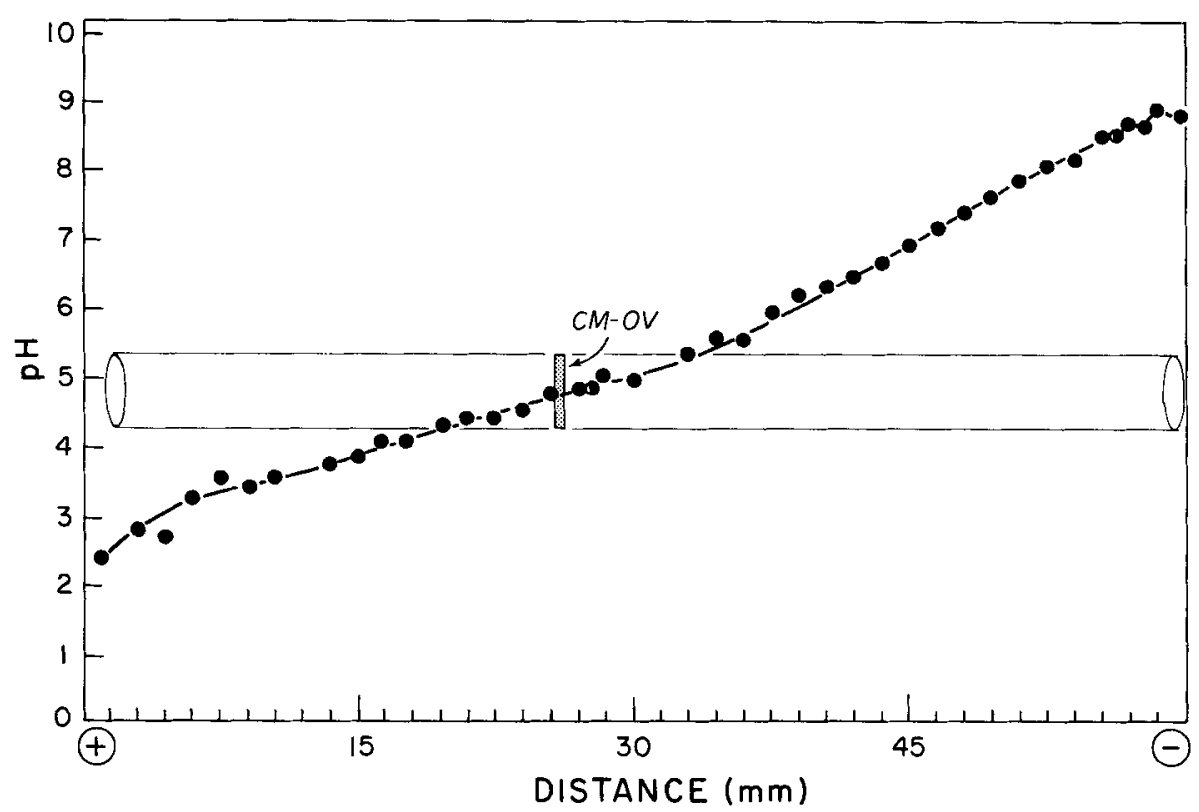

Fig. 2 Chorioallantoic membrane ovomucoid (CM-OV, $100 \mu \mathrm{g} / \mathrm{gel}$ ) was focused in polyacrylamide gel with LKB Ampholine ( $\mathrm{pH} 4$ to 6) as described in MATERIALS AND METHODS. The stipled bar represents the corrected location of the protein-staining band on the gel. The $\mathrm{pH}$ profile was determined from duplicate gels which were cut in to $1.75 \mathrm{~mm}$ slices and eluted; the $\mathrm{pH}$ was determined after elution of each gel slice with $1 \mathrm{ml}$ of distilled water for 12 hours. The $\mathrm{pH}$ values are indicated by the closed circles.

standard. Immunoelectrophoresis was carried out at $4^{\circ} \mathrm{C}$ for 2 hours and $50 \mathrm{~min}$ utes at $15 \mathrm{~mA}$. The bath and gel buffers were diluted 1 to 1 with water to reduce running time. All samples migrated toward the anode. To increase the staining sensitivity, the slides were washed overnight with $0.85 \%$ saline and the agar surface covered with moistened filter paper and allowed to air dry. The slides were then stained (30 minutes) in a solution containing 1.25 g Coomassie Brilliant Blue G 250, $44 \mathrm{ml}$ glacial acetic acid, $454 \mathrm{ml}$ of $50 \%$ methanol, and $50 \mathrm{ml}$ of glycerol. The staining solution was filtered through What man no. 1 paper prior to use. The slides were destained for 20 minutes in a solution of $75 \mathrm{ml}$ glacial acetic acid, $50 \mathrm{ml}$ methanol, and $875 \mathrm{ml}$ water.

\section{Detection and quantitation of radioactive materials}

Radioactive compounds were detected on paper electrophoretograms or chromatograms with a Packard Radiochromatogram Scanner, Model 7200. Areas containing radioactivity were cut out, immersed in a toluene cocktail recommended by the manufacturer, and quantitated in a liquid scintillation spectrometer (Catsimpoolas, '68 and Bray, '60).

\section{Paper chromatography}

Paper chromatograms were irrigated in a descending fashion on Whatman no. 1 paper with the following solvent systems (v/v): (A) ethyl acetate - pyridine - water $(8: 2: 1)$; (B) redistilled phenol saturated with a water - ammonium hydroxide mixture (100:1) containing several crystals of sodium cyanide; (C) $n$-butanol - pyridine $0.1 \mathrm{~N}$ hydrochloric acid (5:3:2); and (D) $n$-butanol - pyridine - water (6:4:3). Chromatograms developed with solvent $D$ were dipped into $1 \%$ sodium tetraborate, blotted and air dried prior to sample application.

\section{High voltage paper electrophoresis}

High voltage paper electrophoresis was performed with a Gilson Model D high voltage paper electrophorator. In all cases, samples were applied to Whatman 3MM 
TABLE 1

Physical and biological properties of chorioallantoic membrane ovomucoid (CM-OV)

\begin{tabular}{ll}
\hline $\mathrm{D}_{20}$ (Ficks) & 8.00 \\
$\mathrm{~s}_{211, \mathrm{w}}$ & 3.00 \\
$\mathrm{v}$ & $0.695 \mathrm{ml} / \mathrm{g}$ \\
$\mathrm{pI}$ & 4.8 \\
Molecular weight determined $\mathrm{by:}$ \\
$\quad$ sedimentation velocity & 30,000 \\
$\quad$ sodium dodecylsulfate & $29,500 \pm 500$ \\
$\quad$ gel electrophoresis & 1.001 \\
Trypsin inhibition & 0.5 to $20 \mu \mathrm{g}^{2}$ \\
\hline
\end{tabular}

${ }^{1} \mathrm{CM}-\mathrm{OV}(\mu \mathrm{g})$ required to inhibit $1 \mu \mathrm{g}$ of trypsin.

${ }^{2} \mathrm{CM}-\mathrm{OV}(\mu \mathrm{g})$ required to elicit positive Evans Blue skin test (Halpern, '56).

chromatography paper previously saturated with either buffer $\mathrm{E}(1.25 \mathrm{M}$ pyridine $-0.07 \mathrm{M}$ acetic acid, $\mathrm{pH} 6.4$ ) or buffer $\mathrm{F}$ ( $1 \%$ sodium tetraborate, $\mathrm{pH} 8.4$ ).

\section{Detection of compounds on paper chromatograms and paper electrophoretograms}

Neutral sugars were detected on paper chromatograms with a silver nitrate dip reagent (Trevelyn and Harrison, '52) or a periodate-benzidine procedure (Gordon et al., '56). N-Acetylhexosamines were detected with a $p$-dimethylaminobenzaldehyde spray reagent (Partridge, '49). Amino acids were visualized with a ninhydrin dip reagent (Smith, '60).

\section{Serum specimens}

Before hatching, blood was obtained from the chorioallantoic blood vessels, after hatching by heart puncture. Samples were allowed to clot at $23^{\circ}$ for 1 hour and the serum was harvested by centrifugation at $1465 \mathrm{~g}$ for 10 minutes; all samples were stored at $4^{\circ} \mathrm{C}$ until use.

\section{Surgical removal of yolk sacs}

In experiments designed to locate ovomucoid, yolk sacs were removed 2 days after hatching. The chicks were anesthetized with pentobarbital ( $1.6 \mathrm{mg} / \mathrm{chick}$ ), the yolk sac stalk ligated at 2 points and surgically removed. Sham-operated chicks served as controls.

\section{Purification of CM-OV from chorioallantoic membranes}

Unless otherwise stated, all subsequent operations were performed at $0^{\circ}$ to $4^{\circ} \mathrm{C}$. All dialyses were performed against at least 2 changes of 20 volumes of distilled water for 24 hours. Freshly collected chorioallantoic membranes from 20 dozen 12.5 day embryos were washed twice with 41 cold distilled water. The isolated membranes were homogenized with an equal volume of distilled water at top speed in a Virtis homogenizer for 6 minutes; the membrane preparation was cooled in a salt-ice bath at 2 minute intervals. The homogenate was centrifuged at $1465 \mathrm{~g}$
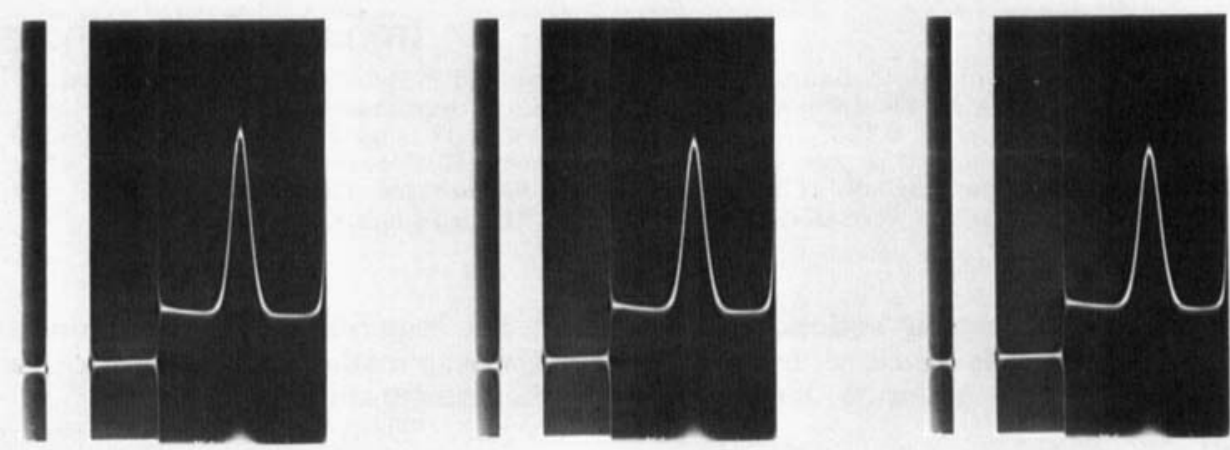

Fig. 3 Sedimentation velocity patterns of chorioallantoic membrane ovomucoid (CM-OV). Photographs of Schlieren patterns obtained with a phase plate angle of $70^{\circ}$ were taken 16 , 24 , and 32 minutes after attaining a speed of $59,780 \mathrm{rpm}$. Protein (CM-OV, $15 \mathrm{mg} / \mathrm{ml}$ ) was dissolved and dialyzed against $0.05 \mathrm{~m}$ potassium phosphate, $\mathrm{pH} 6.8$. The direction of sedimentation was from left to right. 


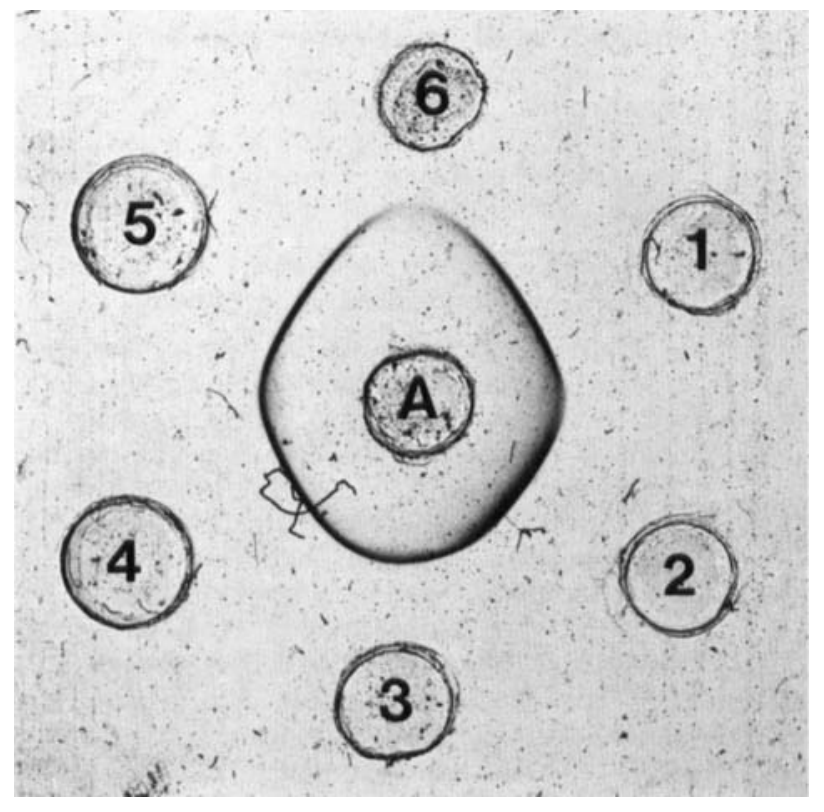

Ouchterlony Double Diffusion

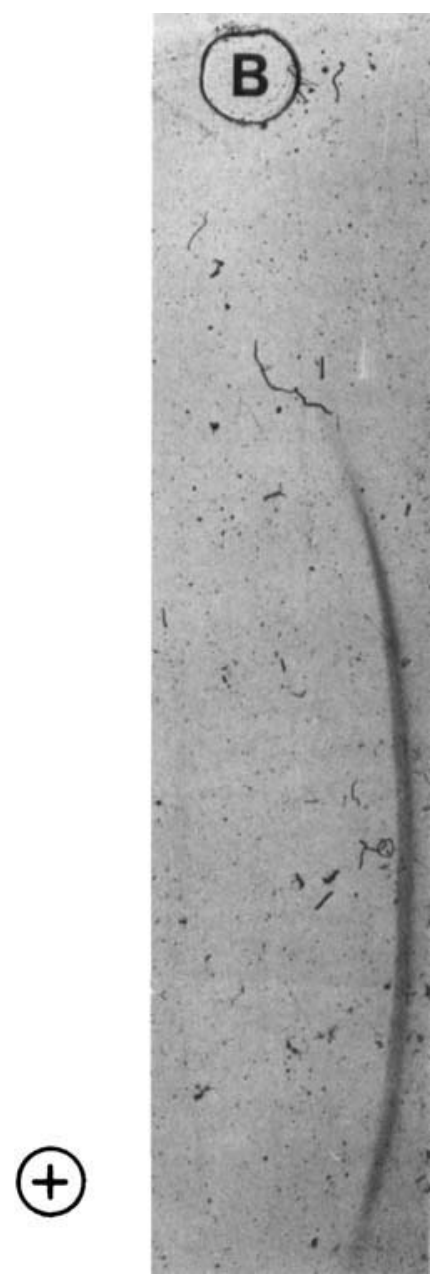

Immunoelectrophoresis

Fig. 4 Reaction of chorioallantoic membrane ovomucoid (CM-OV) with rabbit anti CM-OV. Well $A$ (Ouchterlony double diffusion) contained rabbit anti-ovomucoid and wells 1 to 6 were filled with $2,1,0.5,0.25,0.125$, and $0.0625 \mathrm{mg} / \mathrm{ml}$ of CM-OV, respectively. Well $B$ (immunoelectrophoresis) contained a solution of CM-OV $(1 \mathrm{mg} / \mathrm{ml})$. CM-OV was electrophoresed in $0.05 \mathrm{M}$ barbital buffer, pH 8.2, at 5 milliamperes for 90 minutes. The trough was filled with anti CM-OV. Components were allowed to diffuse at $23^{\circ} \mathrm{C}$ for 24 hours.

for 10 minutes to remove cellular debris. The supernatant was clarified by centrifugation at $78,480 g$ for 2 hours and dialyzed.

Step 1. Zinc chloride fractionation. The dialyzed supernatant was adjusted to a final concentration of $0.05 \mathrm{M}$ zinc chloride by the slow addition of $1 \mathrm{M}$ zinc chloride. The precipitated protein was removed by centrifugation at $4080 \mathrm{~g}$ for $10 \mathrm{~min}$ - utes. The supernatant solution containing CM-OV was made $0.025 \mathrm{M}$ with respect to sodium citrate and dialyzed.

Step 2. DEAE-Cellulose fractionation. The clarified material from Step $1(1.27 \mathrm{~g})$ was placed on a $200 \mathrm{ml}$ column of DEAEcellulose chloride $(2 \mathrm{~cm}$ in diameter) and eluted in a sequential fashion with 10 volumes each of water, $0.03 \mathrm{M}$ potassium chloride, and $0.05 \mathrm{~m}$ potassium chloride. 
The $0.05 \mathrm{M}$ potassium chloride fraction which contained the major portion of $\mathrm{CM}-\mathrm{OV}$ was pooled and dialyzed against 20 volumes of $0.001 \mathrm{M}$ potassium phosphate, $\mathrm{pH} 6.8$, for 12 hours.

Step 3. Hydroxylapatite fractionation. The dialyzed sample from Step 2 was adsorbed in a batchwise fashion on hydroxylapatite $(5 \mathrm{mg}$ protein $/ \mathrm{ml}$ packed gel volume). The gel contained in a $250 \mathrm{ml}$ centrifuge tube was washed sequentially with 10 volumes of the following concentrations of potassium phosphate buffer, $\mathrm{pH}$ 6.8: $0.001 \mathrm{M}, 0.04 \mathrm{M}$, and $0.06 \mathrm{~m}$. With each buffer change the gel was gently stirred and centrifuged at $4080 \mathrm{~g}$ for 10 minutes. The CM-OV fraction eluted with $0.04 \mathrm{M}$ potassium phosphate buffer and was dialyzed against distilled water.

Step 4. DEAE-Cellulose fractionation with a linear $p H$ gradient. The dialyzed CM-OV fraction (Step 3) was made $2.5 \mathrm{~mm}$ with respect to potassium phosphate and potassium citrate, adjusted with $1 \mathrm{~N}$ potassium hydroxide to $\mathrm{pH} 6.5$, and placed on a $20 \mathrm{ml}$ column of DEAE-cellulose chloride $(0.9 \mathrm{~cm}$ diameter $)$ equilibrated with the same buffer. The column was eluted with a linear $\mathrm{pH}$ gradient ( $\mathrm{pH} 6.5$ to 3.0). The mixing chamber contained phosphatecitrate buffer adjusted to $\mathrm{pH} 6.5(100 \mathrm{ml})$ and the reservoir contained the same buffer adjusted to $\mathrm{pH} 3.0(100 \mathrm{ml})$. The flow rate was $0.5 \mathrm{ml} / \mathrm{minute} ; 2.5 \mathrm{ml}$ fractions were collected. Fractions (67 to $78 \mathrm{ml}$ ) contained CM-OV and were pooled and dialyzed.

Step 5. Discontinuous fractionation of $C M-O V$ on CM-cellulose. The DEAE fraction from Step 4 (20 mg protein) was adjusted to $5 \mathrm{~mm}$ with respect to the acetate ion with $1 \mathrm{~m}$ potassium acetate $(\mathrm{pH} 4.5)$ and placed on a $4 \mathrm{ml}$ column of CM-cellulose potassium $(0.5 \mathrm{~cm}$ diameter $)$ equilibrated with the same buffer. The column was eluted with increasing concentrations of potassium chloride in the above buffer $(\mathrm{pH} 4.5)$ at final concentrations of $5 \mathrm{~mm}$, $30 \mathrm{~mm}$, and $70 \mathrm{~mm}$. The flow rate was $1 \mathrm{ml} /$ minute and $1 \mathrm{ml}$ fractions were collected. The chorioallantoic glycoprotein (CM-OV, $12 \mathrm{mg}$ ) was eluted with $70 \mathrm{~mm}$ potassium chloride as a symmetrical peak. The fraction was pooled, dialyzed, and lyophilized.

\section{Assay for glycosidase activity}

Several glycosidases were present in crude yolk sac membrane extracts. Each glycosidase was assayed (Kuby and Lardy, 53) under conditions in which the product formation was linear with respect to time and protein concentration. Each assay mixture contained $p$-nitrophenylglycoside, $20 \mathrm{~mm}$; sodium acetate ( $\mathrm{pH} 4.0), 125 \mathrm{~mm}$; and 0.005 to $0.020 \mathrm{ml}(0.01$ to $1 \mathrm{mg}$ pro-

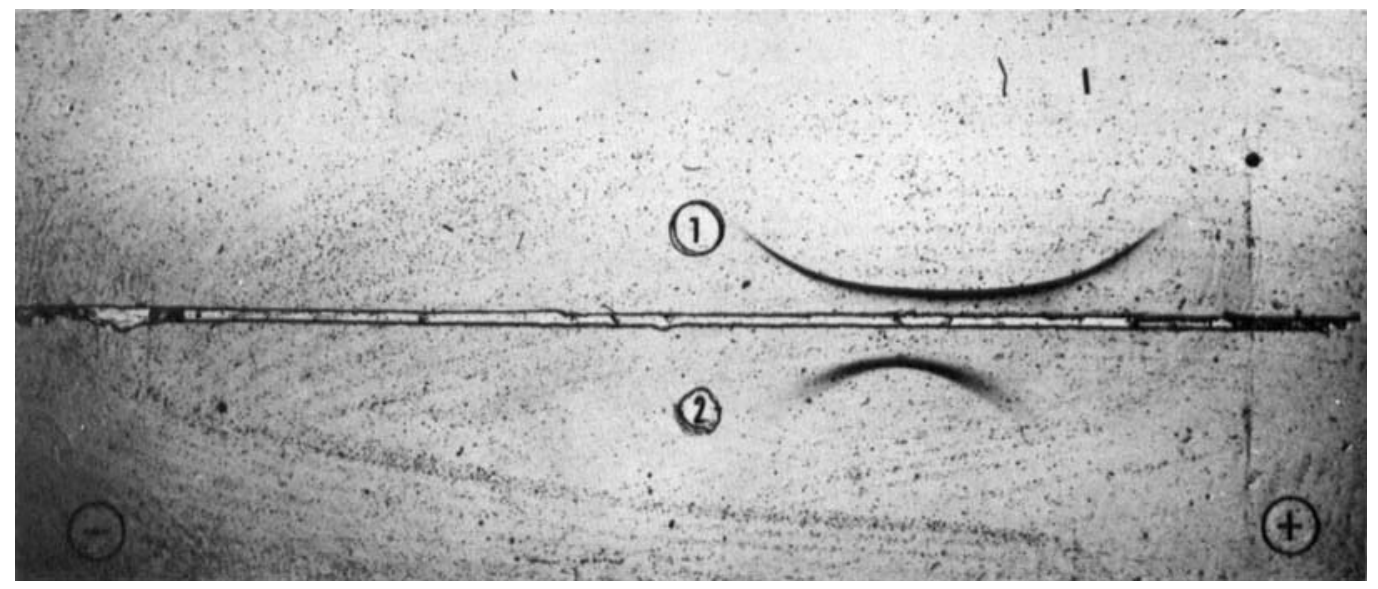

Fig. 5 Results of chorioallantoic membrane ovomucoid (CM-OV) and whole egg white with rabbit anti CM-OV. The upper well (1) contained White Leghorn egg white (2 mg/ml); the lower well (2) contained CM-OV. After electrophoresis in barbital buffer, pH 8.2, for 90 minutes at 5 milliamperes, the center trough was filled with rabbit anti CM-OV and the components were allowed to diffuse at $23^{\circ} \mathrm{C}$ for 24 hours. 
tein) of enzyme extract in a final volume of $0.05 \mathrm{ml}$. All incubations were conducted at $37^{\circ} \mathrm{C}$. To stop the reaction and to enhance the color of the $p$-nitrophenolate ion, $1.2 \mathrm{ml}$ of $0.25 \mathrm{M}$ glycine, $\mathrm{pH} 9.7$, was added to each reaction tube. Absorbance was read at $410 \mathrm{~nm}$. Optimal $\alpha$-mannosidase activity required the presence of zinc ions (as zinc chloride) in a final concentration of $0.001 \mathrm{M}$.

\section{Incorporation of ${ }^{1 \cdot 4} \mathrm{C}$-amino acids into embryonic chick serum proteins and ovomucoid}

${ }^{14} \mathrm{C}$-Algae protein hydrolysate $(5 \mu \mathrm{Ci})$ was injected into the peritoneal cavity of 13 and 18 day embryos and 4 day old chicks. Eight hours after injection, serum samples were collected as described above. Serum aliquots $(0.025 \mathrm{ml})$ were spotted on $2 \mathrm{~cm}$ squares of Whatman 3MM chromatography paper, dried, and heated in $5 \%$ trichloroacetic acid at $70^{\circ} \mathrm{C}$ for $10 \mathrm{~min}$ utes. The paper was washed twice with $200 \mathrm{ml}$ of diethylether and twice with $100 \mathrm{ml}$ acetone, air dried, and the radioactivity was quantitated as described above.

The ovomucoid fraction was prepared from embryo serum $(0.2 \mathrm{ml})$ by addition of $0.5 \mathrm{ml} \mathrm{CM-OV}$ antiserum, $10 \mu \mathrm{g}$ cold carrier ovomucoid, and $10 \mu \mathrm{l} 10 \%$ sodium azide. Mixtures were incubated at $37^{\circ} \mathrm{C}$ for 1 hour and then at $4^{\circ} \mathrm{C}$ overnight. Incubation mixtures were centrifuged at $1465 \mathrm{~g}$ for 10 minutes and the supernatant solutions assayed for ovomucoid and antibody. Precipitates were washed 2 times with cold saline, suspended in saline, and spotted on paper; the ${ }^{14} \mathrm{C}$-content was quantitated in the manner described above.

\section{Determination of the nature of the carbohydrate-amino acid linkage(s) in chorioallantoic ovomucoid preparations}

The conditions of Carlson (66) were used to ascertain whether O-glycosidic linkages exist between the polypeptide core and the carbohydrate chains of $\mathrm{CM}-\mathrm{OV}$. Incubation mixtures contained, in a final volume of $0.15 \mathrm{ml}, 0.16 \mu$ mole of $\mathrm{CM}-\mathrm{OV}$ and $5.64 \mathrm{mg}$ of sodium borotritide $(74 \mu \mathrm{Ci} / \mathrm{millimole})$ in $0.05 \mathrm{~N}$ sodium hydroxide. The resulting product(s) was hydrolyzed at $100^{\circ} \mathrm{C}$ for 2 hours in $2 \mathrm{~N}$ hydrochloric acid, neutralized with excess Dowex-1 (bicarbonate) and passed through a $5 \mathrm{ml}$ column of Dowex-50 (hydrogen). An aliquot of the neutral fraction was chromatographed for 20 hours in a descending manner on Whatman no. 1 paper with solvent $D$. The hexosamine fraction was eluted from the Dowex-50 column with $50 \mathrm{ml}$ of $0.5 \mathrm{~N}$ hydrochloric acid, taken to dryness in vacuo, $\mathrm{N}$-acetylated (Roseman and Ludowieg, '54) and the aliquots subjected to paper electrophoresis on Whatman 3MM saturated with buffer $F$ for 30 minutes at 70 volts $/ \mathrm{cm}$. Material that migrated at the same rate as authentic $N$-acetylglucosaminitol was eluted and acid hydrolyzed with $2 N$ hydrochloric acid at $100^{\circ}$ for 1 hour. The hydrolyzed sample $(0.05 \mu$ mole) was taken to dryness in vacuo, treated with dansylchloride (Morse and Horecker, '66), and subjected to paper

TABLE 2

Qualitative identification of carbohydrate residues of chorioallantoic membrane ovomucoid (CM-OV)

\begin{tabular}{|c|c|c|c|c|c|c|c|c|c|c|}
\hline \multirow{2}{*}{$\begin{array}{l}\text { Chromatography } \\
\text { solvents and } \\
\text { electrophoresis } \\
\text { buffers }\end{array}$} & \multicolumn{3}{|c|}{ Neutral sugar stds. } & \multirow{2}{*}{\multicolumn{3}{|c|}{$\begin{array}{l}\text { Ncutral sugars } \\
\text { in CM-OV }\end{array}$}} & \multicolumn{3}{|c|}{ N-Acetylhexosamine stds. } & \multirow{2}{*}{$\begin{array}{l}\text { N-Acetyl- } \\
\text { hexosamines } \\
\text { in CM-OV }\end{array}$} \\
\hline & Man & Gle & Gal & & & & ManNAc & GalNAc & GlcNAc & \\
\hline$A^{\prime}$ & 1.00 & 0.77 & 0.61 & 1.02 & 0.77 & 0.60 & & & & \\
\hline B 1 & 1.00 & 0.88 & 0.98 & 0.99 & 0.88 & - & & & & \\
\hline $\mathrm{C}^{1}$ & 1.00 & 0.86 & 0.76 & 0.99 & 0.86 & 0.77 & & & & \\
\hline $\mathrm{D}^{2}$ & & & & & & & 1.00 & 1.00 & 1.67 & 1.69 \\
\hline $\mathrm{F}^{3}$ & & & & & & & 1.00 & 0.36 & 0.15 & 0.15 \\
\hline
\end{tabular}

\footnotetext{
${ }^{1}$ Mobility is presented relative to mannose. The chromatograms (Whatman no. 1) were irrigated in a descending fashion for the following time periods: A, 17.5 hours; B, 26 hours; and C, 20 hours.

2 Mobility is presented relative to $N$-acetylmannosamine. The chromatographic sheets (Whatman $3 M M$ paper) were dipped into $1 \%$ sodium tetraborate prior to sample application and then irrigated with solvent $D$ for 8 hours in a descending fashion.

${ }^{3}$ Paper electrophoretograms were run on Whatman 3MM sheets saturated with buffer $\mathrm{F}$ for 30 minutes at 53 volts $/ \mathrm{cm}$.
} 
electrophoresis in buffer $\mathrm{E}$ for 30 minutes at $62 \mathrm{volts} / \mathrm{cm}$. The radioactive material that migrated at the same rate as authentic dansylglucosaminitol was cut out and quantitated.

The presence of a $\beta$-asparaginyl- $N$-acetylglucosamine linkage in the glycopeptide fraction was demonstrated by the procedures of Plummer et al. ('68) and Lis et al. ('66).

\section{RESULTS}

The protein fraction purified from 12.5 day chorioallantoic membranes $(12.5 \mathrm{mg}$ ) represented $0.16 \%$ of the soluble protein fraction and was the only fraction found to contain glucose $(2.4 \mu \mathrm{g} / \mathrm{mg})$. Attempts to isolate CM-OV from chorioallantoic membranes of day 11 and day 14 embryos were unsuccessful. When ovomucoid prepared from egg white by the method of Lineweaver and Murray (47) and commercial ovomucoid were purified by the procedure outlined in this report, the final products contained several protein species as shown by discontinuous polyacrylamide gel electrophoresis at $\mathrm{pH}$ 9.5. However, whole egg white and egg white ovomucoid preparations contained no detectable glucose, i.e., less than $0.1 \mu \mathrm{g}$ glucose/mg protein as determined by gas-liquid chromatography.

\section{Purity of the CM-OV}

The homogeneity of CM-OV was examined by several procedures. Results of the discontinuous polyacrylamide gel electrophoresis at $3 \mathrm{pH}$ values are presented in figure 1. A single protein-staining band was found with protein loads of up to 200 $\mu \mathrm{g} / \mathrm{gel}$ and under staining conditions in which as little as $0.5 \mu \mathrm{g}$ of protein could be detected. Under conditions in which the $\mathrm{pH}$ gradient was approximately $0.1 \mathrm{pH}$ unit/mm (fig. 2), isoelectric focusing in polyacrylamide gel yielded a single protein-staining band with a pI of 4.8 .

When $\beta$-mercaptoethanol-reduced $\mathrm{CM}$ OV $(10$ to $50 \mu \mathrm{g})$ was subjected to sodium dodecylsulfate polyacrylamide gel electrophoresis, a single protein-staining band was observed, with an estimated molecular weight of 29,500 .

A single symmetrical peak was observed in analytical ultracentrifuge studies (fig. 3). The physical parameters of CM-OV are shown in table 1 . Using a calculated partial specific volume of $0.695 \mathrm{ml} / \mathrm{g}$, a molecular weight of 30,000 was obtained, a value in close agreement with that obtained by sodium dodecylsulfate gel electrophoresis.

When purified CM-OV was reacted with anti CM-OV, a single band was found on double diffusion or immunoelectrophoresis plates (fig. 4). When anti CM-OV was reacted with whole egg white or with an extract of chorioallantoic membrane, a single precipitin arc was also obtained (fig. 5). Egg white ovomucoid isolated by the procedure of Oegema and Jourdian (74) and CM-OV reacted to identity with either anti CM-OV or anti egg white ovo-

TABLE 3

Amino acid and carbohydrate compositions of chorioallantoic membrane ovomucoid (CM-OV)

\begin{tabular}{|c|c|c|}
\hline Compound & $\begin{array}{c}\text { Residues/ } \\
\text { mole }\end{array}$ & $\begin{array}{l}\mathrm{g} / 100 \mathrm{~g} \\
\text { protein }\end{array}$ \\
\hline $\begin{array}{l}\text { Alanine } \\
\text { Arginine } \\
\text { Aspartic acid } \\
\text { Half-cystine } 1 \\
\text { Glutamic acid } \\
\text { Glycine } \\
\text { Histidine } \\
\text { Isoleucine } \\
\text { Leucine } \\
\text { Lysine } \\
\text { Methionine } \\
\text { Phenylalanine } \\
\text { Proline } \\
\text { Serine } \\
\text { Threonine } \\
\text { Tyrosine } \\
\text { Valine } \\
\text { D-Glucosamine }{ }^{2} \\
\text { D-Glucose }{ }^{3} \\
\text { D-Galactose } \\
{ }^{3} \\
\text { D-Mannose }{ }^{3} \\
\text { N-Acetylneuraminic } \\
\quad \text { acid }{ }^{4}\end{array}$ & $\begin{array}{c}10.6 \\
5.9 \\
29.8 \\
16.0 \\
14.1 \\
14.5 \\
4.8 \\
2.9 \\
10.6 \\
13.0 \\
1.8 \\
\text { N.D.6 } \\
6.2 \\
10.6 \\
11.0 \\
5.9 \\
12.7 \\
22.8 \\
0.4 \\
1.6 \\
7.4 \\
<0.02\end{array}$ & $\begin{array}{r}3.14 \\
3.84 \\
14.30 \\
6.61 \\
7.59 \\
3.34 \\
2.75 \\
1.36 \\
5.00 \\
6.95 \\
0.98 \\
\\
2.51 \\
3.85 \\
4.64 \\
3.81 \\
5.25 \\
17.417 \\
0.27 \\
1.08 \\
5.00\end{array}$ \\
\hline Percent recovery 5 & & 84 \\
\hline
\end{tabular}

I Determined as cysteic acid (Spencer and Wold, '69).

2 Hexosamine content determined by the method of Roseman and Daffner ('56). The experimental results were obtained after treatment of CM-OV at $100^{\circ}$ with $4 \mathrm{~N}$ hydrochloric acid for 8 hours.

$\overline{3}$ The neutral sugars were determined by gas-liquid chromatography as glycitol acetates after resin-mediated hydrolysis according to the conditions of Lehnhardt and Winzler ('68).

${ }^{4}$ Periodate-resorcinol (Jourdian et al., '71).

5 Percent recovery determined by weight of residues recovered divided by weight of total material assayed.

${ }^{6}$ Not determined.

7 Calculated as $N$-acetylglucosamine. 
mucoid. These results suggested that the antiserum was specific for ovomucoid and could be used for its detection in biological fluids. The availability of large quantities of anti CM-OV prompted its use in the present studies.

\section{Chemical characterization of $\mathrm{CM}-\mathrm{OV}$}

Qualitative characterization of the neutral sugars found in CM-OV was achieved by paper chromatography and electrophoresis; the results are presented in table 2. Optimal conditions for the release of neutral sugars by acid hydrolysis were established by gas-liquid chromatography (fig. 6). Glucose, mannose, and galactose were the only neutral monosaccharides observed; fucose and $N$-acetylneuraminic acid were not detected. After passage of the acid hydrolysates of CM-OV through columns of Dowex-50 (hydrogen), glucosamine was detected in the $0.5 \mathrm{~N}$ hydrochloric acid eluate.

The results of quantitative studies of amino acid and carbohydrate compositions of CM-OV are presented in table 3. The amino acid composition was similar to that found for other ovomucoid preparations (Oegema and Jourdian, '74; Lin and Feeney, '72).

\section{Biological properties of $\mathrm{CM}-\mathrm{OV}$}

The esterase activity of trypsin was inhibited by CM-OV in a manner that sug-

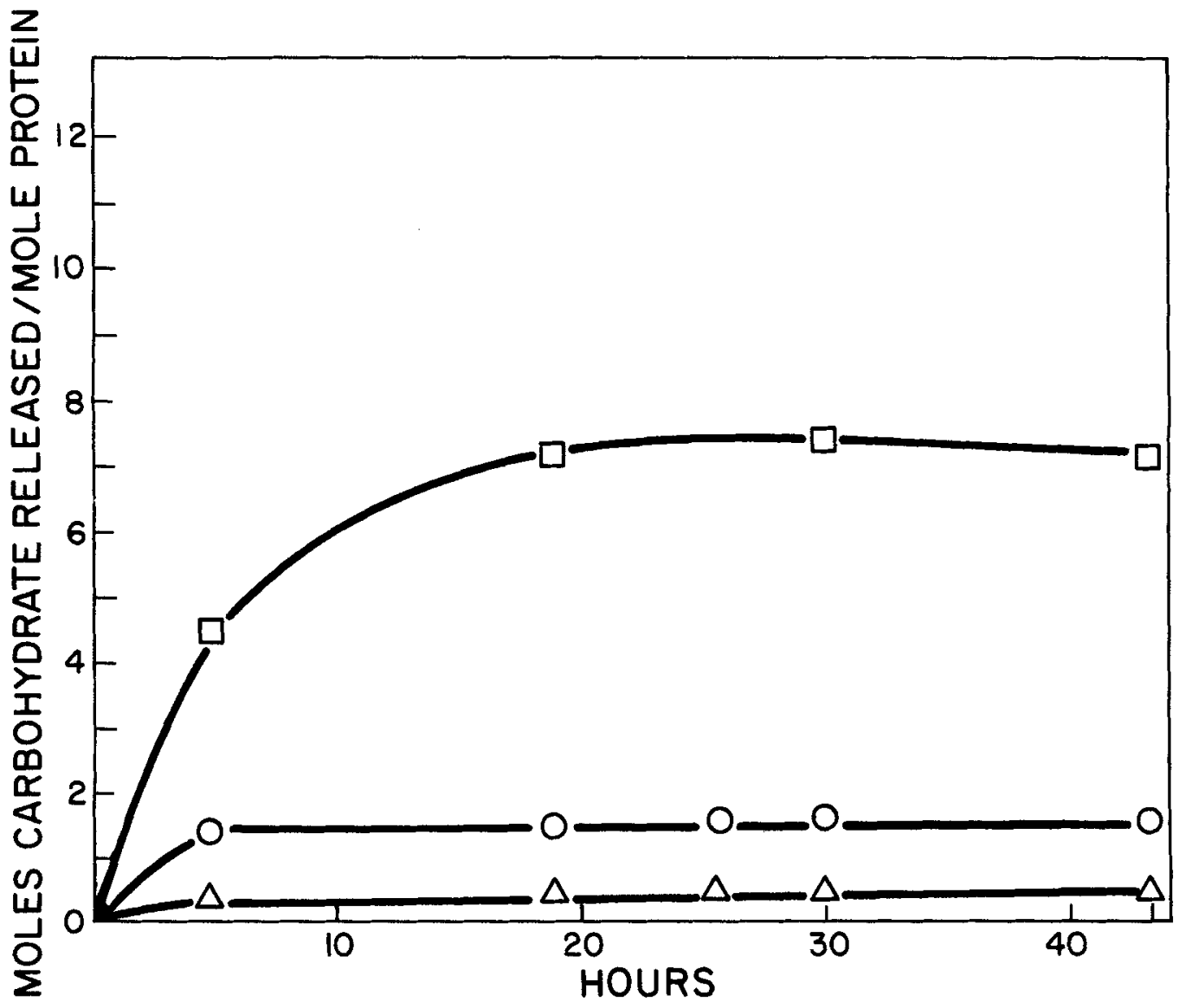

Fig. 6 Rate of release of neutral carbohydrate residues from CM-OV during ion exchangemediated acid hydrolysis. Conditions for hydrolysis and for carbohydrate quantitation are described in MATERIALS AND METHODS; $-\square-\square-$, mannose; $-\mathrm{O}-\mathrm{O}-$, galactose; and $-\Delta-\Delta-$, glucose. 
TABLE 4

High voltage paper electrophoresis of dansylated chorioallantoic ovomucoid (CM-OV) glycopeptide, acid hydrolysis products, and standard compounds

\begin{tabular}{|c|c|c|c|}
\hline \multirow{2}{*}{ Dansylated compounds } & \multicolumn{3}{|c|}{ Migration relative to dansyl- $\mathrm{SO}_{3}$} \\
\hline & Standard cpds. & 10 minutes $^{2}$ & 20 minutes $^{3}$ \\
\hline Aspartic acid & 1.20 & & \\
\hline Dansyl-SO- & 1.00 & 1.00 & 1.00 \\
\hline Dansylamide & 0.84 & 0.84 & 0.82 \\
\hline Asn-GlcNAc & 0.64 & & 0.624 \\
\hline CM-OV Glycopeptide & 0.52 & 0.52 & 0.52 \\
\hline
\end{tabular}

\footnotetext{
${ }^{1}$ Electrophoresis was run in buffer $F$ for 40 minutes at 70 volts $/ \mathrm{cm}$. All compounds migrated toward the anode.

2 Dansylated CM-OV glycopeptide was acid hydrolyzed at $100^{\circ} \mathrm{C}$ for 10 minutes in $2 \mathrm{~N}$ hydrochloric acid.

${ }^{3}$ Dansylated $\mathrm{CM}-\mathrm{OV}$ glycopeptide was acid hydrolyzed at $100^{\circ} \mathrm{C}$ for 20 minutes in $2 \mathrm{~N}$ hydrochloric acid.

${ }^{4}$ This material was eluted from the electrophoretograms, dried, and hydrolyzed at $100^{\circ} \mathrm{C}$ for $90 \mathrm{~min}$ utes in $2 N$ hydrochloric acid. After paper electrophoresis, a fuorescent spot was observed with a relative migration rate of 1.2 .
}

gested formation of a 1 to 1 complex with CM-OV. Halpern ('56) demonstrated that ovomucoid preparations produced an anaphylactoid reaction in albino rats. This finding was confirmed with a homogeneous ovomucoid fraction obtained from egg white (Oegema and Jourdian, '74). In the present study with $\mathrm{CM}-\mathrm{OV}$ as challenging agent, all albino rats tested responded to $20 \mu \mathrm{g}$ of CM-OV and several animals responded positively to $0.5 \mu \mathrm{g}$ of CM-OV.

\section{Structural studies}

The branch points between the carbohydrate chain and the polypeptide core in glycoproteins are comprised of either (1) a base labile $O$-glycosidic bond between the monosaccharide residue initiating a carbohydrate chain and a serine and/or threonine residue contained in the polypeptide core, or (2) a base stabile $N$-glycosidic linkage between aspartic acid and $\mathrm{N}$-acetylglucosamine. Using conditions which promote $\beta$-elimination (Carlson, '66) with borotritide as reducing agent, less than $10: \mathrm{mole} / \mathrm{mole}$ of protein of base labile O-glycosidically linked carbohydrate was found. The only sugar to protein link found in CM-OV glycopeptide preparations was asparaginyl- $N$-acetylglucosamine (table 4).

\section{Translocation of egg white ovomucoid}

Samples of fluid from the amnion, gizzard (stomach), gut, and yolk sac obtained at various stages of chick development were examined by Ouchterlony double diffusion versus anti CM-OV. In unincubated fertilized eggs and up until day 12 of incubation, CM-OV was located in the egg white fraction (table 5). Between days 12 and $13 \mathrm{CM}-\mathrm{OV}$ appeared successively in the amniotic fluid, stomach, gut, and yolk sac. The embryonic serum also contained material that reacted with rabbit anti CM-OV during a period from day 13 of incubation to 8 days after hatching. The results of this quantitative immunochemical study are presented in figure 7 .

Ovomucoid (CM-OV, $2 \mathrm{mg}$ ) was injected into the amniotic sac of 11-day embryos and appeared in serum on day 12 (average $4.2 \mathrm{mg} \%$, std. dev. $\pm 1.9 \mathrm{mg} \%$ ). Ingestion by chicks of $100 \mathrm{mg}$ whole egg white containing $10 \mathrm{mg}$ ovomucoid ( 7 days after hatching) did not result in appearance of $\mathrm{CM}-\mathrm{OV}$ in the serum. Ovomucoid was not detected in saline-injected controls of embryos of the same age.

TABLE 5

Translocation of ovomucoid in the developing chick embryo

\begin{tabular}{cccc}
\hline \multirow{2}{*}{$\begin{array}{c}\text { Day of } \\
\text { development }\end{array}$} & \multicolumn{3}{c}{$\begin{array}{c}\text { Embryos containing } \\
\text { ovomucoid }\end{array}$} \\
\cline { 2 - 4 } & Amnion & Stomach & Yolk sac \\
\hline 11 & 0 & 0 & 0 \\
12 & 17 & 0 & 0 \\
$121 / 4$ & 50 & 0 & 0 \\
$121 / 2$ & 83 & 67 & 0 \\
$123 / 4$ & 100 & 88 & 25 \\
13 & 100 & 100 & 67 \\
14 & 100 & 100 & 100 \\
\hline
\end{tabular}




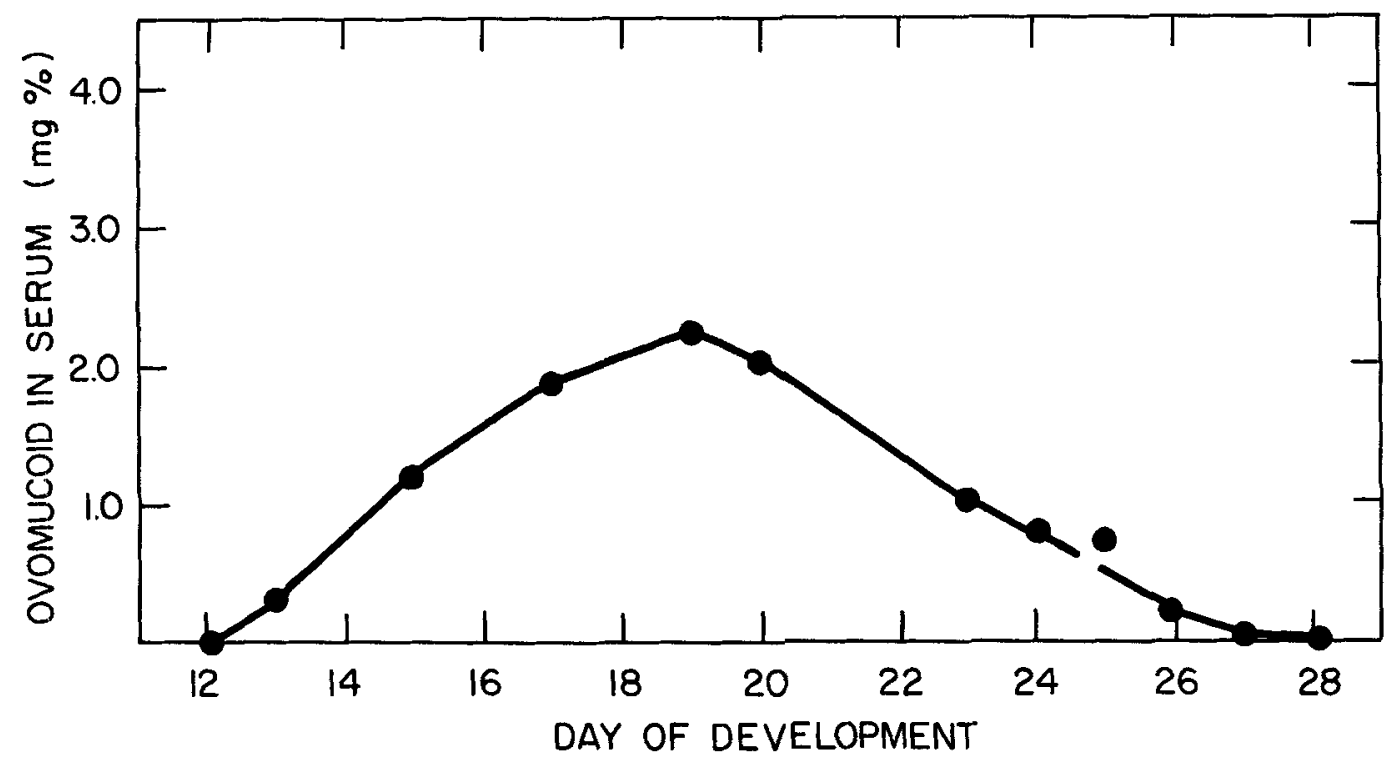

Fig. 7 Occurrence of ovomucoid (CM-OV) in chick embryo serum. The CM-OV content of chick embryo serum was determined by immunoelectrophoresis as described in MATERIALS AND METHODS.

An attempt was made to evaluate the role of the yolk sac in the metabolism of ovomucoid in the serum. The yolk sacs of 2-day old chicks were surgically removed and the levels of CM-OV in the serum examined for 7 days. The CM-OV content in the serum of the surgically treated and control chicks decreased at nearly the same rate: surgically treated chicks, $2 \mathrm{mg}$ $\% /$ day and control chicks, $3 \mathrm{mg} \% /$ day. The half-life of ovomucoid in the serum of the surgically treated chicks varied from 0.5 to 1.2 days.

\section{Synthesis of serum proteins and ovomucoid by the developing chick embryo}

Since Gitlin and Kitzes ('67) had shown that the embryonic yolk sac synthesizes a material immunochemically resembling conalbumin, embryos were examined for their ability to synthesize serum ovomucoid. Embryos were injected with a ${ }^{14} \mathrm{C}$ labeled amino acid mixture and the serum and ovomucoid fractions analyzed for net protein synthesis as described in MATERIALS AND METHODS. The results are shown in table 6. While high levels of radioactivity were found in serum proteins, no detectable ${ }^{14} \mathrm{C}(<60 \mathrm{cpm})$ was incorporated
TABLE 6

Protein synthesis in the chick embryo

\begin{tabular}{cccc}
\hline $\begin{array}{c}\text { Day of } \\
\text { development }\end{array}$ & $\begin{array}{c}\text { Number of } \\
\text { ernbryos }\end{array}$ & $\begin{array}{c}\text { Serum } \\
\text { protein } \\
\text { (cpm/ml) }\end{array}$ & $\begin{array}{c}\text { Serum } \\
\text { ovomucoid } \\
\text { (cpm/ml) }\end{array}$ \\
\hline 15 & 3 & 20,850 & 35 \\
18 & 3 & 40,600 & 64 \\
23 & 5 & 24,450 & 43 \\
\hline
\end{tabular}

${ }^{14} \mathrm{C}$-Algae protein hydrolysate $(5 \mu \mathrm{c}$, specific activity $52 \mu \mathrm{c} / \mu$ atom C) was injected intraperitoneally. The reaction mixtures were incubated at $37^{\circ} \mathrm{C}$ for 8 hours. Assays were performed as described in MATERIALS AND METHODS.

into the ovomucoid fraction, suggesting that appearance of ovomucoid in the serum is not the result of de novo synthesis in the developing embryo but instead represents utilization by the developing embryo of preformed egg white ovomucoid.

\section{Yolk sac glycosidases}

Results of studies concerned with the translocation of CM-OV have suggested that the developing chick embryos possess enzymes capable of rapidly degrading yolk and egg white glycoproteins. By analogy to the metabolism of mammalian glycoproteins (Aronson, '72), it was anticipated that ovomucoid would be degraded by pro- 
teases and glycosidases. Several glycosidases that act on $p$-nitrophenylglycosides were found in the yolk sac membrane; these included: a zinc-dependent $\alpha$-D-mannosidase, a $\beta$-D-mannosidase, $\alpha$-L-fucosidase, $\beta$-N-acetylglucosaminidase, and $\beta$ galactosidase.

An attempt was made to purify $\beta$-galactosidase, $\alpha$-mannosidase, and $\beta$ - $N$-acetylglucosaminidase activities for use as specific reagents to ascertain the sequence of sugar residues comprising the carbohydrate portion of ovomucoid. In contrast to $\beta$-galactosidases isolated from plant, microbial, and mammalian sources, the $\beta$ galactosidase activity found in yolk sac membrane proved exceptionally labile and was unable to be further purified by a number of conventional techniques such as salting out, fractionation by organic solvents, or by ion exchange techniques. The $\alpha$-mannosidase and $\beta$ - $N$-acetylglucosaminidase activities were partially resolved. $\alpha$-Mannosidase preparations exhibited a strict requirement for zinc ions. Each of the glycosidases exhibited a $\mathrm{pH}$ optimum between 3 and 3.5, suggesting a lysosomal origin. The method of Lineweaver and Burk ('34) was used to determine the $K_{m}$ of each glycosidase (with the corresponding $p$-nitrophenyl derivatives as substrates): $\beta$ - $N$-acetylglucosaminidase, $\mathrm{K}_{\mathrm{m}}, 7.0 \mathrm{mM}$; and $\alpha$-mannosidase, $K_{m}, 5.0 \mathrm{~mm}$. Details of these studies will be presented elsewhere.

\section{DISCUSSION}

A specific glycoprotein which resembles ovomucoid appears in the chorioallantoic membrane of the developing chick embryo between days 12 and 13 . The glycoprotein (CM-OV) was isolated and shown to be homogeneous by the following procedures: immunochemical means, disc gel electrophoresis at several $\mathrm{pH}$ values, isoelectric focusing, and ultracentrifugation. The glycoprotein has a molecular weight of $29,500 \pm 500$, inhibits trypsin in a 1 to 1 molar ratio, and elicits an anaphylactoid reaction in albino rats. The amino acid composition of $\mathrm{CM}-\mathrm{OV}$ is similar to that reported for ovomucoid preparations. The carbohydrate portion of the molecule contains galactose, mannose, glucose, and $\mathrm{N}$-acetylglucosamine. The only demonstrable protein to carbohydrate linkage detected was asparaginyl- $\beta-N$-acetylglu- cosamine, in accordance with findings for other ovomucoid preparations (Lin and Feeney, '72). Chorioallantoic membrane ovomucoid (CM-OV) had lower $N$-acetylglucosamine, galactose, and mannose contents than other ovomucoid preparations (Lin and Feeney, '72). The finding of 0.4 mole of covalently bound glucose per mole of CM-OV was unexpected; glucose was not detected in egg white glycoprotein or commercial ovomucoid preparations. Indeed, glucose is found in relatively few glycoproteins. These include: (1) a proposed brain hyaluronic acid complex (Wardi et al., '66); Chakrapani and Bachhawat, '68); (2) an aorta glycoprotein (Radhakrishnamurthy et al., '66); (3) a urine glycoprotein (Bourillon et al., '61); (4) a glycoprotein from neoplastic ascitic fluid (Sugimoto, '56); (5) a sialoglycoprotein from the cortical gray matter of calf brain (van Nieuw Amerongen et al., '72); and (6) collagen (Butler and Cunningham, '66). It is probable that a portion of the egg white ovomucoid is both catabolically and anabolically altered at or on the villae of the chorioallantoic membrane as the membrane extends into the egg white during embryo development to give CM-OV.

In the present studies utilizing $\mathrm{CM}-\mathrm{OV}$ antiserum, ovomucoid was detected in the albumin fraction of fertilized eggs only up until day 12 of embryo development. Between days 12 and 13, ovomucoid was found successively and in increasing amounts in the amniotic fluid, stomach, gut, and yolk sac. During the same period, ovomucoid was detected in the serum of the embryo. Its appearance in the serum is probably due to transport across the wall of the gut into the circulatory system of the embryo. The presence of ovomucoid (CM-OV) in the serum 24 hours after its injection into the amnionic sac (on day 11) suggests that the controlling factor in egg white utilization is the rupture of serio-amnion raphe. This hypothesis supports and extends observations of other investigators (Foote, '69; Romanoff, '60). It is not known if the small quantities of ovomucoid found in the serum play a specific role in the developing embryo. It was established that immediately after hatching the passage of "intact" ovomucoid across the gut ceases, since the ingestion of ovomucoid or whole egg white 
did not result in appearance of detectable amounts of ovomucoid in serum. Surgical removal of the yolk sac from the chick (which continues to contain a significant amount of ovomucoid for at least one week after hatching) immediately after hatching did not alter the rate of disappearance of ovomucoid from the serum. This observation suggests that the yolk sac does not contribute to metabolism of the serum ovomucoid during days 2 to 7 after hatching.

Preliminary studies revealed that when reaction mixtures containing ovomucoid and yolk sac homogenates were incubated (for periods as long as 48 hours) and then challenged with ovomucoid-specific antiserum, the number of precipitin lines observed with time on Ouchterlony double diffusion plates increased from 1 to 5 , followed by disappearance of all immunoreactivity at 48 hours. These studies demonstrate that the yolk sac membrane contains the requisite enzymes for degradation of the glycoprotein portion of ovomucoid. Ito (57) has reported that the yolk sac contains sulfydryl-activated protease(s); however, native egg white protein was not used as substrate. The presence of several glycosidase activities $(\alpha-$ and $\beta$-galactosidase, $\alpha$ - and $\beta$-mannosidase, $\beta-N$-acetylhexosaminidase, $\alpha$-glucosidase, $\alpha$-fucosidase, and $\beta$-glucuronidase) strongly suggests that the carbohydrate portion of ovomucoid is also degraded in the yolk sac membrane.

Results presented in this paper suggest the following sequence of steps during utilization of egg white glycoproteins by the developing chick embryo. Little or no egg white protein is metabolized by the embryo until day 12 of development. Between days 12 and 13 , the serio-amnionic raphe ruptures and the egg white proteins flow into the amnionic sac and are swallowed by the embryo. The protein then passes through the digestive tract and the bulk of the material is transported to the yolk sac and catabolized by the digestive enzymes present in the yolk sac membrane. During transport through the digestive tract, a small portion of protein leaks through the gut wall into the circulatory system.

\section{LITERATURE CITED}

Aronson, N. N. 1972 Degradation of glycopro- teins by lysosomal enzymes. In: Glycoproteins. Vol. 5, part B. A. Gottschalk, ed. Elsevier Publishing Co., New York, pp. 1211-1227.

Bourillon, R., R. Got and J. Michon 1961 Les glycoproteins de l'urine. II. Etude d'une fraction de l'adialysable soluble dans l'ethanol a' 65\%. Clin. Chim. Acta, 6:91-98.

Bray, G. A. 1960 A simple efficient liquid scintillator for counting aqueous solutions in a liquid scintillation counter. Anal. Biochem., 1; 279-285.

Butler, W. T., and L. W. Cunningham 1966 Evidence for the linkage of a disaccharide to hydroxylysine in tropocollagen. J. Biol. Chem., 241 : 3882-3888.

Carlson, D. M. 1966 Oligosaccharides isolated from pig submaxillary mucin. J. Biol. Chem., $241: 2984-2986$.

Catsimpoolas, N. 1968 Micro isoelectric focusing in polyacrylamide gel columns. Anal. Biochem., 26: 480-482.

Chakrapani, B., and B. K. Bachhawat 1968 Glycosaminoglycans of human urine. Part $\mathrm{I}-$ Protein-polysaccharide linkage region in the non sulphated glycosaminoglycans of normal urine. Indian J. Biochem., 5: 9-12.

Chervenka, C. H. 1969 Determination of sedimentation rates. In: A Manual of Methods for the Analytical Ultracentrifuge. Beckman Instruments, Inc., Palo Alto, California, pp. 23-37.

1969 Determination of diffusion coefficients. In: A Manual of Methods for the Analytical Ultracentrifuge. Beckman Instruments, Inc., Palo Alto, California, pp. 83-86.

Chrambach, A., R. A. Reisfeld, M. Wyckoff and J. Yaccari 1967 A procedure for rapid and sensitive staining of protein fractionated by polyacrylamide gel electrophoresis. Anal. Biochem., 20: 150-154.

Crowle, A. J. 1961 Immunodiffusion. Academic Press, New York, p. 303.

Davis, B. J. 1964 Disc gel electrophoresis. Part I1. Ann. N. Y. Acad. Sci., 121:404-427.

Distler, J., and G. W. Jourdian 1972 UDP-Glucose: $\beta$-xyloside transglucosylase from embry onic chick brain. Methods Enzymol., 28: 482485.

Dubois, M., K. A. Gilles, J. K. Hamilton, P. A. Rebers and F. Smith 1956 Colorimetric method for determination of sugars and related substances. Anal. Chem., 28: 350-356.

Edsall, J. T. 1943 Apparent molal volume, heat capacity, compressibility and surface tension of dipolar ions in solution. In: Proteins, Amino Acids, and Peptides. E. J. Cohn and E. J. Edsall, eds. Reinhold Publishing, Inc., New York, pp. 155-174.

Foote, F. M. 1969 Translocation of albumin in eggs and embryos of the quail, chick, and duck. Poultry Sci., 48: 304-306.

Fredericq, E., and H. F. Deutsch 1949 Studies on ovomucoid. J. Biol. Chem., 181:499-510.

Gibbons, R. A. 1972 Physico-chemical methods for the determination of purity, molecular size, and shape of glycoproteins. In: Glycoproteins. Vol. 5, part A. A. Gottschalk, ed. Elsevier, New York, pp. 31-128.

Gitlin, D., and J. Kitzes 1967 Synthesis of serum albumin, embryo-specific $\alpha$-globulin and conalbumin by chick yolk sac. Biochem. Biophys. Acta, 147: 334-340. 
Gordon, H. T., W. Thornburg and L. N. Werum 1956 Rapid paper chromatography of carbohydrates and related compounds. Anal. Chem., 28: 849-855.

Grabar, P., and C. A. Williams 1953 Méthode permettant l'étude conjuguée des propriétés électrophorétiques et immunochimiques d'un mélange de protéines. Application au sérum sanguin. Biochim. Biophys. Acta, 10: 193-194.

Green, N. M. 1953 Competition among trypsin inhibitors. J. Biol. Chem., 205: 535-551.

Halpern, B. N. 1956 Histamine release by long chain molecules. In: Histamine, Ciba Foundation Symposium. Little Brown Co., Boston, pp. 92-193.

Ito, Y. 1957 L'Attivita' delle protein asi del tuorlo e del sacco del tuorlo durante to suiluppo del' uovo di pollo. Acta Embryo. et Morphol. Expt'l., 1: 118-130.

Jourdian, G. W., L. Dean and S. Roseman 1971 The sialic acids. XI. A periodate-resorcinol method for the quantitative estimation of free sialic acids and their glycosides. J. Biol. Chem., $246: 430-435$.

Kuby, S. A., and H. A. Lardy 1953 Purification and kinetics of $\beta$-D-galactosidase from Escherichia coli, strain K-12. J. Am. Chem. Soc., 75: 890-896.

Laurell, C.-B. 1966 Quantitative estimation of proteins by electrophoresis in agarose gel containing antibodies. Anal. Biochem., 15: 45-52.

Lehnhardt, W. F., and R. J. Winzler 1968 Determination of neutral sugars in glycoproteins by gas-liquid chromatography. J. Chromatog., $34: 471-479$.

Lin, Y., and R. E. Feeney 1972 Ovomucoid and ovoinhibitors. In: Glycoproteins. Vol. 5, part B. A. Gottschalk, ed. Elsevier Publishing Co., New York, pp. 762-781.

Lineweaver, H., and D. Burk 1934 The determination of enzyme dissociation constants. J. Am. Chem. Soc., 56: 658-666.

Lineweaver, H., and C. W. Murray 1947 Identification of the trypsin inhibitor of egg white with ovomucoid. J. Biol. Chem., 171: 565-581.

Lis, H., N. Sharon and E. Katchalski 1966 Soybean hemagglutinin, a plant glycoprotein. J. Biol. Chem., 241: 684-689.

Lowry, O. H., N. J. Rosebrough, A. L. Farr and R. J. Randall 1951 Protein measurement with the Folin phenol reagent. J. Biol. Chem., 193: 265-275.

Maurer, H. R. 1971 Methods of analytical disc gel electrophoresis. In: Disc Electrophoresis and Related Techniques of Polyacrylamide Gel Electrophoresis. Walter de Gruyter, New York, pp. 32-116.

Menzies, I. S., and J. W. T. Seakins 1969 Sugars. In: Chromatographic and Electrophoretic Techniques. Vol. I Chromatography, Third Edition. I. Smith, ed. William Heinemann Medical Books, Ltd., London, pp. 310-329.

Mörner, C. Th. 1894 Ueber eine im nühnereiweiss in reichlichen menge vorkemmende mucinsubstanz. Z. Physiol. Chem., 18: 525-532.

Morse, D., and B. L. Horecker 1966 Thin-layer chromatography separation of DNS-amino acids. Anal. Biochem., 14: 429-433.

Oegerna, T. R., Jr., and G. W. Jourdian 1974 The physical and chemical properties of a chicken egg white glycoprotein purified by non-denaturing methodology. Arch. Biochem. Biophys., 160: 26-39.

Ornstein, L. 1964 Disc electrophoresis. Part I. Ann. N.Y. Acad. Sci., $121: 321-349$.

partridge, S. M. 1949 Aniline hydrogen phthalate as a spraying reagent for chromatography of sugars. Nature, 164: 443 .

Plummer, T. H., Jr., A. Tarentino and F. Maley 1968 The glycopeptide link age of ribonuclease B. J. Biol. Chem., 243: 5158-5164.

Radhakrishnamurthy, B., and G. S. Berenson 1966 Glycopeptides from bovine aorta glycoprotein. J. Biol. Chem., 241: 2106-2112.

Reisfeld, R. A., U. J. Lewis and D. E. Williams 1962 Disc gel electrophoresis of basic proteins and peptides on polyacrylamide gels. Nature, 195: 281-283.

Romanoff, A. L. 1952 Membrane growth and function. Ann. N.Y. Acad. Sci., 55: 288-301, 1960 The Avian Embryo. The MacMillan Co., New York, 1305 pp.

Roseman, S., and I. Daffner 1956 Colorimetric method for determination of glucosamine and galactosamine. Anal. Chem., 28: 1743-1746.

Roseman, S., and J. Ludowieg 1954 N-Acetylation of the hexosamines. J. Am. Chem. Soc., $76: 301-302$.

Schwert, G. W., and Y. Takenaka 1955 A spectrophotometric determination of trypsin and chymotrypsin. Biochem. Biophys. Acta, 16: $570-575$.

Selye, H. 1937 Studies on adaptation. Endocrinology, 21: 169-188.

Skrivanek, J. D. 1964 Assimilation of albumen in the chick embryo. Amer. Zool., 4: 403. Abstr. 123.

Smith, I. 1960 Chromatographic and Electrophoretic Techniques. Vol. 1. I. Smith, ed. Inter science Publishers, Inc., New York, pp. 95-96.

Spackman, D. H., W. H. Stein and S. Moore 1958 Automatic recording apparatus for use in the chromatography of amino acids. Anal. Chem., 30: 1190-1206.

Spencer, R. L., and F. Wold 1969 A new convenient method for estimation of total cystinecysteine in proteins. Anal. Biochem., 32: 185190.

Sugimoto, K. 1956 CLXXXVIII. Chemical nature of KIK factors. 2. KIK factor in cancerous ascitic fluid. Tohuku J. Expt'l. Med., 64: 271280.

Trevelyan, W. E., and J. S. Harrison 1952 Studies on yeast metabolism. Biochem. J., 50: 298-303.

van Nieuw Amerongen, A., D. H. van den Eijnden, J. Heijlman and P. A. Roukema 1972 Isolation and characterization of a soluble glucosecontaining sialoglycoprotein from the cortical grey matter of calf brain. J. Neurochem., 19 : 2195-2205.

Wardi, A. H., W. S. Allen, D. L. Turner and Z. Stary 1966 Isolation of arabinose containing hyaluronate peptides and xylose-containing chondroitin sulfate peptides from protease-digested brain tissue. Arch. Biochem., Biophys., 117: 44-53.

Weber, K., and M. Osborn 1969 The reliability of molecular weight determinations by dodecylsulfate-polyacrylamide gel electrophoresis. J. Biol. Chem., 244: 4406-4412. 